\title{
Occurrence of Mastitis at Cow and Udder Quarter Level in the Agro- Pastoral District of Soroti, Uganda
}

\author{
Zirintunda $\mathbf{G}^{1 *}$, Ekou $\mathrm{J}^{1}$, Omadang $\mathrm{L}^{1,2}$, Mawadri $\mathrm{P}^{1,2}$, Etiang $\mathrm{P}$ and Akullo $\mathbf{J}^{\mathbf{1}}$ \\ ${ }^{1}$ Department of Animal Production and Management, Faculty of Agriculture and Animal Sciences, Busitema University, Soroti, Uganda \\ ${ }^{2}$ National Livestock Resources Research Institute, National Agricultural Research Organization, Tororo, Uganda
}

\begin{abstract}
A cross sectional study was carried in Aloet Parish, Soroti district-Uganda to assess and quantify the prevalence of mastitis of lactating cows at cow level in the villages and udder quarter level for cows brought for sale at the Soroti livestock market. The objective was to acquire an empirical basis for stakeholders' awareness in the small holder pastoral zones.

Both clinical and subclinical mastitis were quantified at the village level and only SCM was considered at the market level. In the villages and the market SCM was tested using California Mastitis Test (CMT). In the villages of Aloet, $4(12.5 \%)$ of the crosses and 60 (22.4\%) Small East African zebu had mastitis. Overall, SCM and CM were at $50(16.7 \%)$ and $14(4.7 \%)$ occurrence and SCM was responsible for $78 \%$ of all the mastitis. Predisposing factors to mastitis among the pastoralists in communal grazing systems in Aloet were possibly habits such as stripping of teats using rough abrasion of fingers during milking coupled with none usage of milking salves. In the market, the right fore (RF) had a $34.2 \%(27 / 79)$ SCM and $1.25 \%(1 / 80)$ blind quarters. Right hind (RH) had a $30.8 \%(24 / 78)$ SCM and $2.5 \%$ (2/80) blind quarters. The left fore (LF) had a $36.6 \%(27 / 78)$ SCM and $2.5 \%(2 / 80)$ blind quarters. The left hind (LH) had a $31.4 \%(22 / 70)$ SCM and $12.5 \%$ blind quarters. The quarter prevalence rates were higher for the fore quarters than for the hind quarters. For all the quarters SCM prevalence was at 32.8\% (100/305) and 4.9\% (15/320) were blind. Bovine mastitis is an escalating hindrance to the upcoming dairy industry in agro-pastoral areas and requires urgent measures, SCM is possibly confounded by poor performance of local breeds and poor feeding management.
\end{abstract}

Keywords: Clinical; Subclinical; Mastitis; Prevalence

Abbreviations: SCM: Subclinical Mastitis; CM: Clinical Mastitis; SCC: Somatic Cell Count; RH: Right Hind; RF: Right Fore; LH: Left Hind; LF: Left Fore; -: Negative; +: Mild gel; ++: Real gel; +++: Clumps and High Viscosity gel; T: Traces of gel; B: Blocked teat.

\section{Introduction}

Mastitis affects dairy animals and their production [1-3]; it leads to pathological changes in the milk and the glandular tissue [4]. Bovine mastitis can be categorized as clinical (CM) or subclinical mastitis (SCM) where the former manifests changes in the appearance of milk with obvious signs of inflammation of the udder whereas the later doesn't show obvious signs but its effects on can be detected by subjecting the milk to tests [5]. The disease causes losses of reduced production and the milk acquires undesirable components like ions and enzymes while decreasing in casein which leads to an undesired taste [6,7]. Mastitis reduces milk quantity and quality [8,9] and may cause death of the cow [10]. The etiological agent for mastitis produce toxins that damage milk producing tissue and ducts [9]. SCM is difficult to diagnose because the milk appear normal, however, it is the most prevalent compared to the CM $[11,12]$. SCM and CM are wide spread in small scale dairy sector in sub-Saharan Africa [13]. SCM is thought to be more economically important because it persists longer in the herd causing production losses [14-18]. Although more quarters may be affected in SCM, it is usually one quarter affected in CM except when caused by Mycoplasma spp $[19,20]$. CM and SCM affect not only production but even the reproductive performance of lactating animals $[21,22]$. Mastitis associated losses are estimated at more than $\$ 200$ per cow per year [23]; bovine mastitis affects farmers' economy and may continue to be a problem even after meticulous control methods [2].

The major causing agents of mastitis are Staphylococcus aureus, Streptococcus dysagalactiae, coagulase-negative staphylococcus,
Arcanobacterium pyogenes, E. coli, Staphylococcus simulans, Staphylococcus hycus, Staphylococcus chromogenes, Klebsiella spp, Pseudomonas spp and Mycoplasma spp [24-30]. However any bacterial and mycotic organism that can opportunistically invade the udder may cause mastitis. Mammary epithelial cells play a key role in the onset of the process of defense therefore mastitis with regard to E. coli and S. aureus [31]. Infections may be contagious or environmental but contaminated teat dips, udder towels, laborers, skin lesions teat trauma and flies have been implicated as sources of infection [12,32]. The major risk factors are water scarcity. Detection of SCM is best done by examining of milk for somatic cell counts (SCC) using the California Mastitis Test (CMT) or automated methods. Normal milk should have below 200,000 SCC/ $\mathrm{ml}$, milk showing traces of viscosity has 200,000-400,000 SCC/ml, milk showing a mild gel has $500,000-1,500,000 \mathrm{SCC} / \mathrm{ml}$, milk that shows a real gel has 2,000,000-5,000,000 SCC/ml and the milk which shows clumps with very high viscosity has over $5,000,000 \mathrm{SCC} / \mathrm{ml}$ [33]. The agro-pastoral communities depend on livestock especially cattle of low milk production capacities, milk is gathered from many animals and sold to the neighborhoods or taken to the dairies for processing. Milk production is a way of boosting the household economy and taxes for

*Corresponding author: Zirintunda G, Faculty of Agriculture and Animal Sciences, Department of Animal Production and Management, Busitema University P.O. Box 203, Soroti, Uganda, Tel: +256 774234165 , +256704089080; E-mail: gzerald777@gmail.com

Received February 27, 2017; Accepted March 25, 2017; Published March 28, 2017

Citation: Zirintunda G, Ekou J, Omadang L, Mawadri P, Etiang P, et al. (2017) Occurrence of Mastitis at Cow and Udder Quarter Level in the Agro-Pastoral District of Soroti, Uganda. J Vet Sci Technol 8: 432. doi: 10.4172/2157-7579.1000432

Copyright: ( $) 2017$ Zirintunda G, et al. This is an open-access article distributed under the terms of the Creative Commons Attribution License, which permits unrestricted use, distribution, and reproduction in any medium, provided the original author and source are credited. 
the local governments however farmers have inadvertently not done any intervention on mastitis. The farmers and therefore the government are suffering losses because there is no clear basis for sensitization. The study also affirms whether the communities are at risk; since bacterial contamination leading to mastitis provides mechanisms for spread of milk transmissible zoonoses [34].

\section{Materials and Methods}

This was a cross-sectional study carried out in the Aloet Parish, Soroti Sub County of Soroti district. The purpose was to cover the Soroti livestock market and the surrounding villages. The study was divided into two sections: one considering the herds in the villages of Aloet parish and the second considering the lactating cows brought to the cattle market. At villages level, 300 cows were randomly selected and tested for mastitis. Clinical mastitis was observed by the signs of obvious inflammation of an udder quarter or more than one and visible changes in milk for example presence of blood or pus in the milk. SCM was detected using the CMT test. For the villages of Aloet, the details of the quarters and the grades of SCM were not included. In the Soroti livestock market, 10 lactating animals were tested for SCM at udder quarter levels weekly for 8 weeks making a total of 80 cows and the results were graded as Negative (-) meaning those with no observable reactions observed, Traces $(\mathrm{T})$; were some trace of viscosity were seen, Mild (+) were a mild gel was formed, severe $(++)$ were real gels were formed and very severe $(+++)$ were clumps with high viscosity were seen [33]. Only the severe and the very severe grades were assumed to be SCM during the calculation of the percentage SCM infection.

\section{Results}

\section{From the villages of aloet parish}

A total of 300 cows were examined and tested, 32 were crosses and 268 were the East African zebu (locals). Among the crosses $4(12.5 \%)$ had mastitis and among the locals $60(22.4 \%)$ had mastitis. SCM and CM were at (50) $16.7 \%$ and (14) $4.7 \%$ prevalence, SCM was over $78 \%$ of the observed mastitis in the area as shown in Table 1 below.

\section{SCM at udder-quarter level in the soroti livestock market}

The RF had a $34.2 \%(27 / 79)$ SCM and $1.25 \%(1 / 80)$ blind quarters. The RH had a $30.8 \%(24 / 78)$ SCM and $2.5 \%(2 / 80)$ blind quarters. The LF had a $36.6 \%(27 / 78)$ SCM and $2.5 \%(2 / 80)$ blind quarters. The LH had a $31.4 \%$ (22/70) SCM and $12.5 \%$ blind quarters. For all the quarters, SCM was at $32.8 \%(100 / 305)$ and $4.9 \%(15 / 320)$ were blind as shown in Tables 2 and 3 below.

\section{Discussion}

\section{From the villages of aloet parish}

Local cows had higher prevalence of mastitis (22.4\%) compared to the crosses $(12.5 \%)$, this was possibly a statistical challenge because we had more locals than crosses during the study. This is contrary to the findings of Sharma and Maiti [35] who found a higher prevalence of Mastitis in Holstein-Jersey crosses compared to the local Zebu although Rahman et al. [36] found no significant difference of mastitis prevalence between Holstein-Friesian and Zebu. The findings are almost in agreement with Biffa et al. [37] who found Mastitis more prevalent in local Zebu than Jersey although the prevalence in Friesians was more than in local Zebu. However, farmers tend to offer crosses better conditions and care because they consider them not only more productive but also more susceptible to diseases. SCM was $16.7 \%$ prevalent while CM was $4.7 \%$ prevalent, it agrees with the findings of Joshi and Gokhale [16] who found SCM between $10 \%$ and $50 \%$ in the dairy farms of India. However, this prevalence was low because the study was done in a dry season which is usually cleaner. The prevalence of SCM was much lower than the $51.8 \%$ observed by Tripura et al. [38] in Bangladesh and the $37.2 \%$ observed by Byarugaba et al. [7] in the small holder dairy farming systems in Uganda. SCM was responsible for $78 \%$ of mastitis in the area, this agrees with the studies of Byarugaba et al. [39] in North Kyadondo county-Kampala district of Uganda; Kassa et al. [11] in the Ethiopian Central Highlands; Kivaria et al. [12] in the small holder dairy cows in Tanzania; Mdegela et al. [40] in Kibaha and Morogoro districts of Eastern Tanzania. Challenges of tick control could be responsible for the high mastitis prevalence [2]. However the high prevalence of mastitis was possibly because of the low hygiene standards in the communal grazing systems; such systems are associated with primitive tendencies of having no dry cow therapy, not using milking salve and inadvertent transfer of bacteria from one cow to another by the milkers. The farmers usually have rough hands because of the garden work and these bruise the teats and sometimes maneuvers in overgrown grasses and thickets leads to the trauma of teats predisposing them to mastitis. The primitive tendencies of rough dragging away of suckling calves leads to wounds on teats culminating into mastitis [41] ; this is method used in Soroti and is possibly one of the causes for the observed mastitis. The high prevalence of SCM compared to CM was also possibly because the farmers have no idea about this condition which only requires testing; this is in agreement with Karimuribo et al. [42], Sharma et al. [2] and Kivaria [5].

\section{SCM per quarter in the lactating cows in soroti livestock market}

SCM was highest in LF quarter followed by RF, LH and RH; this agrees with Khanal and Pandit, [43] and Tripura et al. [39] who found the LF with the highest prevalence. Possibly shorter duration of increase and decline milk phases predisposes to SCM because Tancin et al. [44] found a shorter duration in the fore quarters compared to the hind quarters. Possibly the fore quarters easily touch the ground during sitting and the hind quarters are in the groins for animals with small

\begin{tabular}{|c|c|c|c|c|c|c|c|c|}
\hline Village & No.sampled & SCM & $\%$ & $\mathrm{CM}$ & $\%$ & $\mathbf{x}^{2}$ & OR & P-value \\
\hline Teso college West & 46 & 10 & 21.7 & 04 & 8.7 & 3.033 & $3.02(10.79,14.32)$ & 0.09 \\
\hline Teso college East & 34 & 08 & 23.5 & 02 & 5.9 & 2.6606 & $4.8(0.86,50.40)$ & 0.08 \\
\hline Arabaka & 34 & 09 & 26.5 & 00 & 00 & 10.3729 & - & 0.002 \\
\hline Ogolo & 29 & 05 & 17.2 & 02 & 6.9 & 1.4622 & $2.8(0.41,31.57)$ & 0.42 \\
\hline Aloet akum & 36 & 04 & 11.1 & 03 & 8.3 & 0.1582 & $1.4(0.2,10.09)$ & 0.69 \\
\hline Abalang & 31 & 03 & 9.7 & 02 & 6.5 & 0.2175 & $1.5(0.16,19.77)$ & 0.64 \\
\hline Arapai Agric & 31 & 04 & 13 & 01 & 3.2 & 1.9579 & $4.4(0.40,225.75)$ & 0.35 \\
\hline Akaikai & 29 & 04 & 13.8 & 00 & 00 & 4.2963 & - & 0.11 \\
\hline Aloet central & 30 & 03 & 10 & 00 & 00 & 3.1579 & - & 0.08 \\
\hline Total & 300 & 50 & 16.7 & 14 & 4.7 & 19.3363 & $3.3(1.8,6.3)$ & $<0.001$ \\
\hline
\end{tabular}

Table 1: Prevalence of SCM and CM in Aloet parish. 
Citation: Zirintunda G, Ekou J, Omadang L, Mawadri P, Etiang P, et al. (2017) Occurrence of Mastitis at Cow and Udder Quarter Level in the AgroPastoral District of Soroti, Uganda. J Vet Sci Technol 8: 432. doi: 10.4172/2157-7579.1000432

Page 3 of 5

\begin{tabular}{|c|c|c|c|c|c|c|c|}
\hline \multirow{2}{*}{ Variable } & \multirow{2}{*}{ Quarters } & \multicolumn{6}{|c|}{ Percentage grades of mastitis (\%) } \\
\hline & & Negative ( - ) & Mild gel (+) & Real gel (++) & High viscosity (clumps) (+++) & Blind quarters (B) & Traces $(\mathrm{T})$ \\
\hline \multirow{4}{*}{ Week 1} & RF & 20 & 10 & 40 & 0 & 0 & 30 \\
\hline & RH & 20 & 50 & 20 & 0 & 0 & 10 \\
\hline & LF & 30 & 20 & 40 & 0 & 0 & 10 \\
\hline & LH & 30 & 10 & 30 & 0 & 20 & 10 \\
\hline \multirow{4}{*}{ Week 2} & $\mathrm{RF}$ & 50 & 30 & 0 & 20 & 0 & 0 \\
\hline & $\mathrm{RH}$ & 70 & 10 & 10 & 10 & 0 & 0 \\
\hline & LF & 50 & 20 & 10 & 10 & 0 & 10 \\
\hline & LH & 50 & 10 & 10 & 10 & 20 & 0 \\
\hline \multirow{4}{*}{ Week 3} & RF & 50 & 30 & 0 & 10 & 10 & 0 \\
\hline & $\mathrm{RH}$ & 60 & 10 & 20 & 0 & 0 & 10 \\
\hline & LF & 50 & 10 & 40 & 0 & 0 & 0 \\
\hline & LH & 40 & 40 & 10 & 10 & 0 & 0 \\
\hline \multirow{4}{*}{ Week 4} & $\mathrm{RF}$ & 40 & 20 & 10 & 30 & 0 & 0 \\
\hline & $\mathrm{RH}$ & 30 & 30 & 20 & 20 & 0 & 0 \\
\hline & LF & 30 & 20 & 20 & 10 & 10 & 10 \\
\hline & LH & 30 & 10 & 20 & 20 & 10 & 10 \\
\hline \multirow{4}{*}{ Week 5} & RF & 20 & 10 & 20 & 50 & 0 & 0 \\
\hline & $\mathrm{RH}$ & 10 & 10 & 40 & 0 & 20 & 20 \\
\hline & LF & 10 & 20 & 20 & 40 & 10 & 0 \\
\hline & LH & 10 & 0 & 20 & 40 & 20 & 10 \\
\hline \multirow{4}{*}{ Week 6} & $\mathrm{RF}$ & 80 & 10 & 0 & 0 & 0 & 10 \\
\hline & $\mathrm{RH}$ & 80 & 10 & 0 & 0 & 0 & 10 \\
\hline & LF & 100 & 0 & 0 & 0 & 0 & 0 \\
\hline & LH & 80 & 0 & 0 & 0 & 20 & 0 \\
\hline \multirow{4}{*}{ Week 7} & $\mathrm{RF}$ & 50 & 10 & 10 & 30 & 0 & 0 \\
\hline & $\mathrm{RH}$ & 50 & 0 & 20 & 30 & 0 & 0 \\
\hline & LF & 20 & 30 & 20 & 30 & 0 & 0 \\
\hline & LH & 30 & 20 & 0 & 30 & 10 & 10 \\
\hline \multirow{4}{*}{ Week 8} & $\mathrm{RF}$ & 30 & 20 & 30 & 20 & 0 & 0 \\
\hline & $\mathrm{RH}$ & 50 & 10 & 20 & 20 & 0 & 0 \\
\hline & LF & 50 & 20 & 10 & 20 & 0 & 0 \\
\hline & LH & 60 & 0 & 10 & 30 & 0 & 0 \\
\hline
\end{tabular}

-: Negative test; T: Traces; +: Mild gel; ++: Real gel; +++: Presence of clumps and high viscosity and B: Blind quarter.

Table 2: Grades of mastitis at the udder quarter level among the lactating animals brought to the Soroti livestock market.

\begin{tabular}{|c|c|c|c|c|c|c|}
\hline \multirow[t]{2}{*}{ Quarter } & \multicolumn{5}{|c|}{ CMT Result } & \multirow[b]{2}{*}{$B$} \\
\hline & - & $\mathrm{T}$ & + & ++ & +++ & \\
\hline $\mathbf{R F}$ & 34 & 04 & 14 & 11 & 16 & 01 \\
\hline RH & 37 & 05 & 12 & 12 & 12 & 02 \\
\hline LF & 34 & 03 & 14 & 16 & 11 & 02 \\
\hline LH & 33 & 04 & 11 & 08 & 14 & 10 \\
\hline
\end{tabular}

Table 3: Quantifying of grades of mastitis at the udder quarter level among the lactating animals brought to the Soroti livestock market.

udders. The LF being the most affected is associated with side that cows prefer when declining to sit on the ground. However the findings don't absolutely agree with the work of Lancelot et al. [45] in dairy herds in Britany of France; Barkema et al. [46] and Saini et al. [47] in Punjab who found the hindquarters most affected by SCM. The overall SCM for all the quarters was at $32.8 \%$ which is higher than $30.15 \%$ found in the dairy livestock of Lamjung by Khanal \& Pandit [43] and 26.7\% found by Giannechini et al. [48] in West Littoral region in Uruguay. However the observed overall quarter prevalence was lower than $51.6 \%$ observed by Kivaria et al. [49] in Dar-es-Salaam region of Tanzania. The prevalence would have been much higher than observed if it was rainy season [36]; however it was a dry season with few flies and fair sanitation.

The trend of blindness of quarters was highest in LH, the LF and RH had an equal percentage and RF had the smallest percentage. Possibly the LH structure predisposes it to blindness, this partly agrees with Weiss et al. [50] who states that the rear teats are shorter and thicker than the front teats, and this is what predisposes them to infection [51]. The trend possibly is related to trend of untreated mastitis, predisposition to trauma and genetic predisposition. However the real cause of the trend is not explicitly known. The overall quarter blindness of $4.9 \%$ is lower than $8 \%$ that was observed by Khan and Mohammad [52] in Faisalabad, Pakistan. Bovine mastitis is an escalating hindrance to the upcoming dairy industry as seen in Aloet parish, it is perhaps the greatest bottleneck to the transition from subsistence to commercial dairy farming. SCM is possibly confounded by poor performance of local breeds and poor feeding management. Therefore more farmer education and routine testing are needed in order to enable the farmers to maximize production. 
Citation: Zirintunda G, Ekou J, Omadang L, Mawadri P, Etiang P, et al. (2017) Occurrence of Mastitis at Cow and Udder Quarter Level in the AgroPastoral District of Soroti, Uganda. J Vet Sci Technol 8: 432. doi: 10.4172/2157-7579.1000432

Page 4 of 5

\section{Acknowledgement}

We are thankful to the following people for the support in the collection of data; Nyode I, Ongora M, Okello G, Okot S, Atima S, Operemo SP, Etimu I, Aruk I, Obete G, Katumba S, Kahandi J, Oyesigye P, Kisembo G, Nancha M, Buwembo L, Isabirye A, Pithuwa J, Nagudi N and Nakiwendo B. The Farmers of Aloet parish were cooperative in this study and the leadership of the Soroti cattle market were so supportive by allowing us to use their lactating animals.

\section{Competing Interests}

The authors declare that they have no competing interests whatsoever.

\section{Funding}

The research was partly facilitated by Busitema University

\section{References}

1. Tiwari JG, Babra C, Tiwari HK, Williams V, De Wet S, et al. (2013) Trends in Therapeutic and Prevention strategies for Management of Bovine Mastitis: An over view. J Vaccines Vacc 4: 176.

2. Sharma N, Rho GJ, Hong YH, Kang TY, Lee HK, et al. (2012) Bovine Mastitis: An Asian perspective. Asian J Anim Vet Adv 7: 454-476.

3. Elango A, Doraisamy KA, Rajarajan G, Kumaresan G (2010) Bacteriology of sub-clinical mastitis and anti-biogram of isolates recovered from cross-bred cows. Indian J Anim Res 44: 280-284.

4. Radostits OM, Gay CC, Blood DC, Hinchkliff KW (2000) A Text Book of Veterinary Medicine $9^{\text {th }}$ Edn. W.B. Saunders, New York, pp: 563-618.

5. Kivaria FM (2006) Epidemiological studies on bovine mastitis in smallholder dairy herds in the Dar es Salaam region, Tanzania. Doctoral thesis, Utrech University, The Netherlands.

6. Hogeveen H (2005) Mastitis in dairy production, current knowledge and future solutions. Wageningen Academic Publishers. ISBN 978-90-76998-70-1 pp:744.

7. Byarugaba DK, Nakavuma JL, Vaarst M, Laker C (2008) Mastitis occurrence \& constraints to mastitis controlin small holder dairy farming systems in Uganda. Livestock Res Rural Dev 20: 1

8. Halasa T, Nielen M, De Ross APW, Van Hoorne R, De Jong G, et al. (2009) Production loss due to new subclinical mastitis in Dutch Dairy cows estimated with a test-day model. J Dairy Sci 92: 599-606.

9. Jones GM, Bailey TL (2009) Understanding the basics of mastitis. Virginia cooperation extension publication 404-233. Accessed on $4^{\text {th }}$ August 2015.

10. Urech E, Puhan Z, Schallibaum M (1999) Changes in milk protein fraction as affected by subclinical mastitis. J Dairy Sci 82: 2402-2411.

11. Kassa T, Wirtu G, Tegegne A (1999) Survey of Mastitis in dairy herds in the Ethiopian Central highlands. Ethiop J Sci 22: 291-301.

12. Kivaria FM, Noordhuizen JP, Kapaga AM (2004) Risk indicators associated with subclinical mastitis in small holder dairy cows in Tanzania. Trop Anim Health Prod 36: 581-592.

13. FAO (2014) Impact of mastitis in small scale dairy production systems. Animal production \&Health working paper. No.13, Rome.

14. Godkin A, Leslie K, Martin W (1990) Mastitis in bulk tank milk culture in Ontario. Highlights 132: 13-16.

15. Kader MA, Samad MA, Saha S (2003) Influence of host level factors on prevalence and economics of subclinical mastitis in dairy cows in Bangladesh. Indian J of Dairy Sci 56: 235-2240.

16. Joshi S, Gokhale S (2006) Status of mastitis as an emerging disease in improved and peri-urban dairy farms in India. Ann NY Acad Sci 1081: 74-83.

17. Halasa T, Huips K, Ǿstras O, Hogeveen H (2007) Economic effects of bovine mastitis and mastitis management: a review. Vet $Q 29: 18-31$.

18. Seeger H, Fourichon C, Beaudeau F (2003) Production effects related to mastitis and mastitis economics in dairy cattle herds. Vet Res 34: 475-491.

19. Contreras A (2012) Detecting Mycoplasma mastitis. Michigan Dairy Review. Accessed on 14th September 2016.

20. Brand T, Kersling KW (1999) Mycoplasma mastitis in Dairy cattle. lowa State
University Veterinarian 61: 4

21. Barker AR, Schrick FN, Lewis MJ, Dowlen HH, Oliver SP (1998) Influence of clinical mastitis during early lactation on reproductive performance of Jersey cows. J Dairy Sci 81: 1285-1290.

22. Schrick FN, Hockett ME, Saxton AM, Lewis MJ, Dowlen H, et al. (2001) Influence of subclinical mastitis during early lactation on reproductive parameters. J Dairy Sci 84: 1407-1412

23. Schroeder JW (2012) Bovine mastitis and milking management (Mastitis control programs). North Dakota State University (NDSU). External Service, AS1129 (Revised)

24. Waage S, Mǿrk T, Rǿros A, Aasland D, Hunshamar A, et al. (1999) Bacteria Associated with clinical mastitis in Dairy heifers. J Dairy Sci 82: 712-719.

25. Barkema HW, Schukken YH, Lam TJGM, Beiboer ML, Wilmink H, et al. (1998) Incidence of clinical mastitis in Dairy Herds grouped in three categories by Bulk milk somatic cell counts. J Dairy Sci 81: 411-419.

26. Busato A, Trachsel P, Schallibaum M, Blum JW (2000) Udder health \& risk factors for subclinical mastitis in organic dairy farms in Switzerland. Prev Vet Med 44: 205-220.

27. Kivaria FM, Noordhuzen JP (2006) A retrospective study of the aetiology \& temporal distribution of bovine clinical mastitis in small holder dairy herds in the Dar es Salaam region of Tanzania. Vet J 173: 617-22.

28. Thorberg BM, Daielsson-Tham ML, Emmanuelson U, Waller KP (2009) Bovine subclinical mastitis caused by different types of coagulase-negative Staphylococci. J Dairy Sci 92: 4962-4970.

29. Plozza K, Llevaart JJ, Potts G, Barkema HW (2011) Subclinical mastitis and associated risk factors on dairy farms in New South Wales. Aust Vet $\mathrm{J} 89$ $41-46$

30. Oliveira L, Hulland C, Ruegg PL (2012) Characterization of clinical mastitis occurring in cows on 50 large dairy herds in Wisconsin. J Dairy Sci 96: 75387549

31. Gilbert FB, Cunha P, Jensen K, Glass EJ, Foucres G, et al. (2013) Differential Response of bovine mammary epithelial cells to Staphylococcus aureus o Escherichia coli agonists of the innate immune system. Vet Res 44: 40.

32. Ohnstad I, Mein GA, Baines JR, Rasmussen MD, Farnsworth R (2007) Addressing teat condition problems. National Mastitis Council, Annual meeting proceedings.

33. Varatanovic N, Podzo M, Mutevelic T, Podzo K, Cengic B, et al. (2010) Use of California Mastitis Test, Somatic Cells Counts and bacteriological findings in diagnostics of subclinical mastitis. Biotech Anim Husbandry 26: 65-74.

34. Sharma N, Singh NK, Bhadwal MS (2011) Relationship of Somatic cell count and mastitis: An overview. Asian-Aust J Animal Sci 24: 429-438.

35. Sharma N, Maiti SK (2010) Incidence, etiology and antibiogram of sub clinical mastitis in cows in Durg, Chhattisgarh. Indian J Vet Res 19: 45-54.

36. Rahman MA, Bhuiyan MMU, Kamal MM, Shamsuddin M (2009) Prevalence \& risk factors of mastitis in dairy cows. The Bangladesh Veterinarian 26: 54-60.

37. Biffa D, Debela E, Beyene F (2005) Prevalence and risk factors of mastitis in lactating dairy cows in Southern-Ethiopia. Int J Applied Res Vet Med. 3: 189-198.

38. Tripura TK, Sarker SC, Roy SK, Parvin MS, Rahman AKMA, et al. (2014) Prevalence of subclinical mastitis in lactating cows \& efficacy of intramammary infusion therapy. Bangladesh J Vet Med 12: 55-61.

39. Byarugaba DK, Khaitoa ML, Opuda A (1998) Bovine mastitis North Kyadondo county of Kampala district. Uganda Vet Journal 4: 139-146.

40. Mdegela RH, Kasiluka LJM, Kapaga AM, Karimuribo ED, Turuka AFM, et al. (2004) Prevalence and determinants of mastitis and milk borne zoonoses in small holder dairy farming sector in Kibaha and Morogoro districts in Eastern Tanzania. J Vet Med B Infect Dis Vet Public Health 51:123-128.

41. Hameed S, Arshad M, Ashraf M, Avais M, Shahid M.A (2012) Cross-sectional epidemiological studies on mastitis cattle and buffaloes of Tehsil Burewala, Pakistan. J Anim Plant Sci 22: 371-376.

42. Karimuribo ED, Fitzpatrick JL, Bell CE, Swai ES, Kambarage DM, et al. (2006) Clinical \& Subclinical Mastitis in small holder dairy farms in Tanzania: risk, intervention\& knowledge transfer. Prev Vet Med 74: 84-98. 
Citation: Zirintunda G, Ekou J, Omadang L, Mawadri P, Etiang P, et al. (2017) Occurrence of Mastitis at Cow and Udder Quarter Level in the AgroPastoral District of Soroti, Uganda. J Vet Sci Technol 8: 432. doi: 10.4172/2157-7579.1000432

43. Khanal T, Pandit A (2013) Assessment of subclinical mastitis and its associated risk factors in dairy livestock of Lamjung, Nepal. Int J Infect Microbiol 2: 49-54.

44. Tancin V, Ipema B, Hogewerf P, Macuhowa J (2006) Sources of variation in milk flow characteristics at udder \& quarter level. J Dairy Sci 89: 978-988.

45. Lancelot R, Faye B, Lescourret $F$ (1997) Factors affecting the distribution of clinical mastitis among udder quarters in French dairy cows. Vet Res 28: 45-53.

46. Barkema HW, Schukken YH, Lam TJGM, Galligan DT, Beiboer ML, et al (1997) Estimation of interdependence among quarters of the bovine udder with subclinical mastitis \& implications for analysis. J Dairy Sci 80: 1592-1599.

47. Saini SS, Sharma JK, Kwatra MS (1994) Prevalence and etiology of subclinical mastitis among cross bred cows and buffaloes in Punjab. Indian J Dairy Sci 47: 103-106.

48. Gianneechini R, Concha C, Rivero R, Delucci I, Lopez JM (2002) Occurrence of clinical and subclinical mastitis in dairy herds in the West Littoral Region in Uruguay. Acta Vet Scand 43: 221-230.

49. Kivaria FM, Noordhuzen JP, Nielen M (2006) Interpretation of California Mastitis Test scores using staphylococcus aureus culture results for screening of subclinical mastitis in low yielding small holder dairy cows in the Dar es Salaam region of Tanzania. Prev Vet Med 78: 274-285

50. Weiss D, Weinfurtner M, Bruckmaier RM (2004) Teat Anatomy \& its relationship with quarter \& udder milk flow characteristics in Dairy cows. J Dairy Sci 87 3280-3289.

51. Zadok RN, Allore HG, Barkema HW, Sampimon OC, Wellenberg GJ, et al (2001) Cow and quarter level risk factors for Streptococcus uberis and Staphylococcus aureus mastitis. J Dairy Sci 84: 2649-2663.

52. Khan AZ, Muhammad G (2005) Quarter wise comparative prevalence of mastitis in buffaloes and cross bred cows. Pakistan Vet J 25: 1. 